\title{
PENGARUH TRANSAKSI HAWALA TERHADAP TINDAK PIDANA TERORISME DI INDONESIA
}

\author{
Imam Subandi, Adji Samekto \\ Program Studi S3 Ilmu Hukum, Fakultas Hukum, Universitas Diponegoro \\ andymarshof@gmail.com
}

\begin{abstract}
Hawala transaction is indeed a transaction that we rarely find especially in Indonesia but not abroad. This is because the hawala transaction is a very confidential transaction that uses high level of trust. This hawala transaction is very likely to be misused for crimes such as money laundering or terrorism financing, but in fact Hawala can also be used for good things such as remittances to regions or other countries with a fast time and cost much cheaper than the remittan system used by banking. In addition, the currency does not have to undergo conversion. Therefore the things that will be of concern in this research is as how hawala transaction done and the influence of hawala in Indonesia especially to terrorism crime in Indonesia? . The method used in this research is explanatory normative research method, that is to explain in detail and systematic facts according to the deductive framework by collecting data through library research and Field Research in this case is the collection and search of data by coming directly to the authorized agencies in the eradication of terrorism, namely the Indonesian National Police in particularly Densus 88 Anti Terror, PPATK and other agencies related to the issues being studied, as well as individuals who considered to know the practice of "HAWALA", through interviews in overt or covert ways with involving the use of intelligence information gathering such as illiciting.
\end{abstract}

Keyword : Hawala.Transaction, Terorism

\begin{abstract}
Abstrak
Transaksi Hawala memang merupakan transaksi yang jarang kita temukan khususnya di Indonesia namun tidak di luar negeri. Hal ini dikarenakan transaksi hawala tersebut memang transaksi yang sangat bersifat rahasia yang menggunakan kepercayaan tingkat tinggi. Transaski hawala ini sangat memungkinkan disalah gunakan untuk kejahatan seperti pencucian uang ataupun pendanaan terorisme, namun sebenarnya Hawala juga bisa digunakan untuk hal-hal yang baik seperti pengiriman uang ke daerah atau Negara lain dengan waktu yang cepat dan biaya yang jauh lebih murah daripada system remittan yang dipakai perbankan. Disamping itu, mata uang tidak harus mengalami konversi. Oleh karena itu hal-hal yang akan menjadi perhatian dalam penelitian ini adalah sebagai berikut adalah bagaimana transaksaksi hawala dilakukan serta pengaruh hawala di Indonesia khususnya terhadap tindak pidana terorisme dengan pengaruh "HAWALA" terhadap upaya pemberantasan tindak pidana terorisme di Indonesia? . Metode penelitian yang akan digunakan dalam penelitian ini adalah metode penelitian normatif yang bersifat eksplanatoris, yaitu menjelaskan secara terperinci dan sistematis fakta-fakta sesuai dengan kerangka pemikiran deduktif dengan pengumpulan data melalui library research dan Penelitian Lapangan
\end{abstract}


dalam hal ini adalah pengumpulan dan pencarian data dengan mendatangi secara langsung instansi-instansi yang berwenang dalam pemberantasan terorisme yakni Kepolisian Negara Republik Indonesia, khususnya Densus 88 Anti Terror, PPATK dan instansi lain yang berkaitan dengan permasalahan yang sedang diteliti, juga individuindividu yang dianggap mengetahui praktek "HAWALA", dengan mengadakan wawancara (interview) baik secara terbuka maupun dengan teknik tertutup seperti eliciting dalam intelijen.

Kata Kunci : Hawala, Transaksi, Terorisme

\section{A. Pendahuluan}

Kata "HAWALA" menurut The Free Dictionary Com adalah: “A system for remitting money, primarily in Islamic societies, in which a financial obligation between two parties is settled by transferring it to a third party, as when money owed by a debtor to a creditor is paid by a person who owes the debtor money. "HAWALA" transactions are usually based on trust and leave no written record."(Thefreedictionary, n.d.)

Sistem ini sulit dideteksi karena didasarkan pada kepercayaan, dan di luar perusahaan yang benar-benar terlibat dalam transaksi, tidak ada orang lain yang perlu tahu tentangnya. Namun, di mana hawaladars beroperasi di dalam negara-negara yang telah mengatur sistem perbankan, kemungkinan sistem akan digunakan oleh hawaladars untuk keamanan. Dengan suksesnya hawaladars di
Inggris yang sering dikirim dan sejumlah besar uang tunai, uang tunai ini perlu diampuni untuk keamanan fisik. Deposito tunai yang sering ini adalah bendera merah - seperti juga transfer internasional pada kesempatan reguler tanpa alasan yang jelas.

Serangan teroris pada 11 September 2001, pemerintah Amerika menduga bahwa beberapa broker "HAWALA" kemungkinan telah membantu organisasi teroris untuk mentransfer uang untuk membiayai kegiatan mereka. Laporan Komisi Penyelidikan peristiwa 11 September telah memastikan bahwa sebagian besar dana yang digunakan untuk membiayai serangan tindakan kejahatan dikirim melalui sistem "HAWALA", dan tidak melalui transfer antar bank walaupun disinyalir melibatkan Bank SunTrust di Florida, di mana dua anggota komplotan telah membuka rekening pribadi. namun 
sebagai akibat dari tekanan yang kuat dari pihak berwenang AS (Badr, 1978)

Proses dari sistem ini menggunakan danayang bisa langsung dibayarkan. Tidak ada birokrasi, jadi penyiksaan membuka rekening bank bisa dihindari dan hanya sedikit atau tidak ada jejak kertas., bila hawaladars menyimpan catatan, mereka akan menunjukkan tanggal, beberapa inisial atau nomor yang akan mengidentifikasi pelanggan ke hawaladar namun tidak mungkin mengungkapkan identitas mereka kepada pihak ketiga yang membaca coulomb, jumlah transaksi, nilai tukar dan identitas ( lagi dalam singkatan atau kode) hawaladar terkait.

$$
\text { Pada bulan November }
$$
2001,Amerika Serikat dibawah pemerintahan Bush membekukan aset Al Barakat, sebuah perusahaan "HAWALA" remittance Somalia terutama digunakan oleh diaspora besar Somalia.Banyak dari agen di beberapa negara pada awalnya ditangkap, meski kemudian dibebaskan setelah tidak ada bukti nyata terhadap mereka yang ditemukan.

Pada bulan Agustus 2006 Al Barakat yang merupakan representasi dari daftar teroris yang dibuat AS assetnya telah dibekukan. Pada bulan
Oktober 2009, Bank al Barakaat cabang Swedia telah dihapus dari daftar jaringan terorisme Perserikatan BangsaBangsa. Perusahaan itu berada di daftar selama delapan tahun, dan mempunyai dana rekening bank yang dibekukan. Menurut Radio pemerintah Swedia SR, PBB tidak menjelaskan mengapa menghapus al-Barakat dari daftar teror. Namun, telah menyarankan bahwa perubahan terbaru dalam posisi Uni Eropa mengenai banyak organisasi "yang sudah terlalu mudah dimasukkan ke dalam daftar teror PBB" mungkin telah mempengaruhi posisi PBB. AlBarakat saat ini telah mampu kembali untuk mengakses dana rekening bank.

Hawala sebenarnya telah dinyatakan ilegal di beberapa negara bagian AS dan negara-negara lain karena terbukti telah digunakan sebagai bentuk pencucian uang dan dapat digunakan untuk memindahkan kekayaan dengan jumlah yang luar biasa.

Artikel ini ingin menjawab permasalahan mengenai bagaimanakah sistem pendanaa Hawala dan pengaruhnya terhadap ancaman dan tindakan terorisme. 


\section{B. Pembahasan}

Hawala adalah sistem transfer uang secara informal, didasarkan pada kehormatan dari jaringan luas pedagang uang yang biasanya berjalan di Timur Tengah, Afrika Utara dan Timur Laut, serta Asia Tenggara.Dalam "HAWALA", bisa dilihat pada contoh , bila A di Arab Saudi ingin mengirimkan uang kepada B di Indonesia, A tinggal menyetorkan uang kepada "HAWALA" dealer di Arab Saudi. Kemudian "B tinggal mencairkan uang itu lewat dealer rekanan di Indonesia."

Komponen integral strategi kontraterorisme A.S. berpusat pada gangguan keuangan teroris. Kelompok teroris telah mengeksploitasi sumber daya dan industri di berbagai negara budidaya opium di Afghanistan, penambangan arang di Somalia, dan penggalian minyak di Irak untuk beberapa nama - untuk dijual di pasar gelap dan kemudian menggunakan dana untuk membayar dan membayar militan.

Salah satu aspek pembiayaan teroris yang paling membingungkan adalah kemampuan organisasi teroris untuk mengarahkan modal dari satu lokasi ke lokasi lain tanpa menggunakan sistem perbankan yang dilembagakan. Kelompok teroris beralih ke jaringan hawala sebagai sarana untuk memindahkan dana tanpa terdeteksi. Hawala, yang berarti "transfer" dalam bahasa Arab, adalah sistem transaksi informal yang sebagian besar didasarkan pada saling percaya. Cara kerja sistem adalah sebagai berikut: Seorang individu di negara A memberi uang kepada pialang hawala, yang dikenal sebagai hawalader, di negara A. Yang kemudian menghubungi hawalader yang beroperasi di negara B dan menginformasikan kepada huruhader tersebut untuk memberikan sejumlah tertentu uang kepada individu tertentu di negara B. Kode disediakan oleh semua pihak untuk memastikan bahwa uang tersebut dikirim ke penerima yang tepat. Para hawalader sendiri tidak mengirim uang fisik; Sebagai gantinya, mereka menyimpan catatan pembayaran dan melunasi hutang di kemudian hari, seringkali melalui pertukaran barang berharga atau bahkan melalui transfer kawat. Selama transaksi, para penjahat membebankan biaya untuk layanan mereka.

Peran jaringan hawala dalam pendanaan teroris disorot dalam laporan bulan Juli 2004 yang dikeluarkan oleh Komisi Nasional untuk Serangan 
Teroris Di Amerika Serikat (juga dikenal sebagai Komisi 9/11). Menurut temuan komisi tersebut, sebelum 9/11, Al Qaeda memindahkan sejumlah uangnya melalui jaringan hawala. "[Osama] Bin Ladin beralih ke jaringan hawala yang mapan yang beroperasi di Pakistan, di Dubai, dan di seluruh Timur Tengah untuk mentransfer dana secara efisien," kata laporan tersebut. "Hawalas menarik bagi al Qaeda karena mereka, tidak seperti lembaga keuangan formal, tidak tunduk pada pengawasan pemerintah yang potensial dan tidak menyimpan catatan rinci dalam bentuk standar.

Saat ini, kelompok teroris, termasuk Taliban, Al Qaeda, dan ISIS, menggunakan jaringan hawala untuk mentransfer dana ke koperasi di seluruh dunia. Sebuah artikel Wall Street Journal Februari 2016 merinci bagaimana ISIS berhasil mendapatkan keuangan melalui jaringan hawala meskipun menghadapi serangan udara dan sanksi A.S. yang ditargetkan.

Kelompok teroris dan pendukung mereka yang beroperasi di Timur Tengah dan Asia Selatan, termasuk Al Qaeda dan afiliasinya, Taliban, dan ISIS, telah dilaporkan menggunakan sistem hawala untuk memindahkan dana," Celina Realuyo, mantan Direktur Program Program Counterterrorism Finance di Departemen Luar Negeri AS, kepada The Cipher Brief. "Baru-baru ini, ada laporan bahwa pejuang asing ISIS menggunakan berbagai metode termasuk transfer kawat dan hawalas untuk mendanai perjalanan dan pengeluaran mereka.

Dana dari jaringan teroris internasional termasuk Al Qaeda sampai saat ini masih terus mengalir ke Indonesia. "Belum diputus sepenuhnya karena mereka membawanya dengan cara hawala, yaitu dengan membawanya secara personal dengan bentuk cash." sehingga dalam hal Keberhasilan dalam menyita atau membekukan asset yang diduga digunakan untuk mendanai terorisme tidak pernah diekspos atau memang belum terlacak.

Proses pendanaan terorisme dapat dilakukan dengan beberapa cara. Namun agar cara yang diambil dapat berjalan secara efektif harus melibatkan banyak pihak. Tentu pemerintah memegang peranan penting dalam hal ini. sebagai contoh di Australia, negara ini banyak dijadikan negara tujuan pelarian dari negara-negara konflik seperti di Timur Tengah. Maka dari itu, 
pemerintah Australia melalui AUSTRAC(Australian Transaction Reports and Analysis Centre), lembaga semacam PPATK di Indonesia, melakukan pengawasan terhadap kegiatan transaksi yang disinyalir merupakan kegiatan pendanaan terorisme. Melalui laporan pendanaan terorisme yang dikeluarkan tahun 2014 . Dalam laporan tersebut AUSTRAC meneliti beberapa transaksi yang menjadi indikator terjadinya pendanaan teroris antara lain:

a) Setoran atau penarikan kas dan juga transfer dana internasional yang menuju ke daerah konflik. Transaksi seperti ini menuju ke beberapa rekening tetapi dalam satu entitas.

b) Beberapa nasabah yang melakukan pengiriman uang internasional ke daerah konflik.

c) Nasabah yang menggunakan variasi nama ketikan mengirimkan uang ke suatu daerah konflik.

d) Setoran dan penarikan kas dari dan kepada re kening organisasi nirlaba tertentu.

e) Transfer dari seorang individu atau organisasi kepada organisasi teroris atau organisasi lain yang terkait dengan organisasi teroris tertentu.

f) Mentransfer sejumlah dana dari rekening perusahaan yang benarbenar baru kepada perusahaan penjual bahan-bahan kimia yang dapat digunakan untuk membuat bom.

g) Aktivitas rekening yang meningkat secara tiba-tiba, inkonsisten dengan profil dari nasabah.

Sebagai bagian dari upaya untuk menekan jaringan hawala terlarang, Departemen Keuangan A.S. telah menyetujui beberapa organisasi hawala yang diketahui yang memiliki hubungan dengan kelompok teroris. Pada 2012, Departemen Keuangan menyetujui tiga jaringan hawala, yaitu Haji Khairullah Haji Sattar Money Exchange (HKHS), Roshan Money Exchange (RMX), dan Rahat Ltd, yang semuanya beroperasi di Afghanistan dan Pakistan, karena mengirim dana ke Taliban. Dua tahun kemudian, Departemen Keuangan memberi sanksi kepada Haji Basir dan Zarjmil Co., kelompok hawala lain yang beroperasi di Pakistan, karena hubungannya dengan Taliban. Di luar organisasi ini, beberapa individu telah ditambahkan ke daftar sanksi A.S. 
untuk memberikan dukungan material kepada Taliban serta Al Qaeda dan ISIS.

Departemen Keuangan, mengutip pejabat Pakistan, memperkirakan bahwa lebih dari \$ 7 miliar mengalir ke Pakistan melalui saluran hawala setiap tahunnya. Memastikan bahwa bagian dari jumlah ini yang menghindar dari tangan teroris adalah tugas yang menakutkan.Pada bulan Oktober 2016, Komite House untuk Keamanan Dalam Negeri mengeluarkan sebuah laporan mengenai usaha A.S. untuk memerangi taktik keuangan yang dilakukan oleh ISIS dan kelompok teroris lainnya. Laporan tersebut menyatakan bahwa "kelemahan yang menganga dalam pelaporan dan pengawasan standar untuk transaksi hawala menghambat upaya untuk mengidentifikasi pemodal ISIS dan meminta pertanggungjawaban lembaga keuangan.

Laporan tersebut merekomendasikan agar Departemen Keuangan bekerja sama dengan negaranegara yang tergabung dalam Financial Action Task Force (FATF) - sebuah badan antar pemerintah yang bertugas mengembangkan tindakan untuk memberantas pencucian uang, pendanaan teroris, dan ancaman terkait lainnya kepada integritas sistem keuangan internasional untuk memperbaiki peraturan pelaporan keuangan dan standar pengawasan untuk memproses pembayaran hawala.Meskipun rekomendasi ini merupakan langkah ke arah yang benar, tantangan yang dihadapi oleh jaringan hawala tetap luas.(Force, 2008) Singkatnya, tidak ada solusi peraturan untuk jaringan hawala.

Osama bin Laden pernah merujuk pada mengambil keuntungan dari 'celahcelah di dalam sistem keuangan Barat.' Sistem hawala tidak retak, ini adalah ngarai.(Bennett Seftel Hawala Networks, 2017). Di Indonesia sendiri tindakan pemberantasan tindak pidana terorisme masih terfokus pada penumpasan jaringan dan para pelaku yang terlibat secara fisik baik langsung maupun tidak langsung. Sehingga tidak heran jika dalam sebuah operasi selalu dimunculkan keberhasilan satgas anti terror dalam menangkap atau menembak mati tersangka teroris dengan berbagai senjata berat dan amunisi.

Indonesia sebenarnya juga telah mempersiapkan paying hukumseperti pada Pasal 11 Peraturan Pemerintah Pengganti Undang-undang Nomor 1 
Tahun 2002 tentang Pemberantasan Tindak Pidana Terorisme yang pada tanggal 4 April 2003 disahkan menjadi Undang-Undang nomor 15 tahun 2003 tentang Pemberantasan Tindak Pidana Terorisme berbunyi: “ Dipidana dengan pidana penjara paling singkat 3 (tiga) tahun dan paling lama 15 (lima belas) tahun, setiap orang yang dengan sengaja menyediakan atau mengumpulkan dana dengan tujuan akan digunakan atau patut diketahui akan digunakan sebagian atau seluruhnya untuk melakukan tindak pidana terorisme sebagaimana dimaksud dalam Pasal 6, Pasal 7, Pasal 8, Pasal 9, dan Pasal 10"(Redaksi, 2003). Selanjutnya secara lebih terperinci dijelaskan dalam pasal 12 Peraturan yang sama yang berbunyi: “ Dipidana karena melakukan tindak pidana terorisme dengan pidana penjara paling singkat 3 (tiga) tahun dan paling lama 15 (lima-belas) tahun, setiap orang yang dengan sengaja menyediakan atau mengumpulkan harta kekakayaan dengan tujuan kan dIgunakan atau patut diketahuinya akan digunakan sebagian atau seluruhnya untuk melakukan tindakan melawan hukum menerima, memiliki, menggunakan, menyerahkan, mengubah, membuang bahan nuklir, senjata kimia, senjata biologis, radiologi, mikroorganisme, radio aktif atau komponennya yang mengakibatkan atau dapat mengakibatkan kematian atau luka berat atau menimbulkan kerusakan harta benda; mencuri atau merampas dan seterusnya..."(Redaksi, 2003)

Pasal 12 ini memang titik beratnya pada penggunaan bahan kimia, biologi, radio aktif dan sejenisnya. Namun secara subsider, tersangka dapat juga dikenakan pasal 13 (tiga belas), yang secara umum mengancam bagi setiap orang yang dengan sengaja memberikan bantuan atau kemudahan terhadap pelaku tindak pidana terorisme dengan memberikan atau meminjamkan uang atau barang atau harta kekayaan lainnya kepada pelaku tindak pidana terorisme; menyembunyikan pelaku tindak pidana terorisme; atau menyembunyikan informasi tentang tindak pidana terorisme, Diancam dengan pidana penjara paling singkat 3 (tiga) tahun dan paling lama 15 (lima belas) tahun.

Mengacu pada pasal-pasal tersebut diatas sangat terbuka bagi pihak berwenang untuk melakukan tindakan lain selain hanya fokus kepada para pelakunya, yakni para penyandang 
dana sehingga dapat memutus jaringan pemasok dana untuk mendukung kejahatan terorisme tersebut. Pendekatan dari undang-undang pajak atau undang-undang mengenai pencucian uang dapat juga diterapkan, tentu saja dengan melibatkan secara aktif PPATK yang dalam hal ini mempunyai otoritas mengawasi transaksi-transaksi yang mecurigakan. Akan tetapi permasalahannya Pusat Pelaporan dan Analisis Transaksi Keuangan (PPATK) mengaku kesulitan menelisik aliran dana teroris yang menggunakan cara Hawala.

Kejadian demi kejadian terorisme yang terjadi di Indonesia membuat polisi maupun instamsi seperti PPATK menjadi sangat waspada, hal tersebut menjadikan polisi mencurigai aliran dana teroris ke tanah air menggunakan cara tersebut. Contoh kasus yang sudah terungkap yaiti Muhammad Jibril yang ditangkap polisi beberapa hari lalu dituding masuk mata rantai aliran dana ini, bila dana tersebut ditransfer lewat cara perbankan konvensional, dengan gampang PPATK bisa mendeteksinya. Sejak 2004, PPATK telah mendeteksi 80 rekening yang terkait aliran dana terorisme dan msih diselidiki.
Pencegahan yang lainnya pada pendanaan terorisme pemerintah Indonesia juga mengeluarkan undangundang terkait tentang pencegahan dan pemberantasan tindak pidana pendanaan terorisme yang tercantum dalam UU No. 9 Tahun 2013. Undang-undang tersebut ditujukan kepada penyedia jasa keuangan untuk dapat mengidentifikasi transaksi keuangan mencurigakan terkait dengan pendanaan terorisme. Untuk menindaklanjuti UU tersebut, maka Pusat Pelaporan dan Analisi Transaksi Keuangan (PPATK) mengeluarkan peraturan Kepala Pusat Pelaporan dan Analisis Transaksi Keuangan Nomor: PER4/1.02/PPATK/03/2014 tentang identifikasi transaksis keuangan mencurigakan bagi penyedia jasa keuangan. Kemudian menurut PPATK beberapa transaksi yang dapat dicurigai sebagai tindakan pencucian uang adalah sebagai berikut:

a) Masuknya dana tunai ke dalam sistem keuangan; dengan jumlah yang mencolokTransaksi keuangan yang dilakukan secara tunai dalam jumlah kumulatif sebesar Rp. 500.000.000,00 (lima ratus juta rupiah) atau lebih atau nilai yang setara, baik dilakukan dalam satu 
kali transaksi maupun beberapa kali transaksi dalam 1 (satu) hari kerja.

b) Pembawaan uang tunai melewati batas negara (cross-border);

c) Transfer antar sistem keuangan;

d) Transfer dari sistem keuangan ke luar sistem keuangan;

e) Pengambilalihan saham atau aset lainnya; dengan Penggabungan perusahaan; atau Pembentukan kelompok usaha .

Pendanaan jaringan teroris di Indonesia sebagian merupakan pendanaan hasil money laundering (pencucian uang). Proses pencucian uang untuk mendanai sebuah organisasi tersebut sering diterapkan oleh organisasi kejahatan termasuk jaringan terorisme. Tujuan dari pencucian uang tersebut antara lain:

a) Menghapus keterkaitan antara kejahatan dengan uang.

b) Menghapus keterkaitan antara pemasok dana dengan penerima dana.

c) Melindungi dana dari kemungkinan adanya penyitaan atau pengambilalihan.

Adapun tahap-tahap pencucian uang sebagai sumber dana terorisme sebagai berikut ; a) Tahap pertama, dana diperoleh melalui kegiatan kriminal, baik itu pencurian maupun perampokan. Hasil dari kegiatan tersebut disimpan ke bank. Tahap ini sangat rawan karena tidak menutup kemungkinan bank dapat mendeteksi transaksi mencurigakan.

b) Tahap kedua, melakukan beberapa transaksi finansial perbankan terhadap uang yang sudah disimpan di bank. Tujuannya adalah untuk menyesatkan deteksi dari penyidik. Dana tersebut terlihat seakan-akan berasal darisumber yang sah.

c) Tahap ketiga ketika dana sudah dinyatakan sah sumbernya dan bebas dari kecurigaan transaksi, maka dana tersebut dikumpulkan kembali melalui kegiatan ekonomi yang sah sebagai misalnya jual-beli barang mewah, investasi dan penanaman saham pada aset seperti perusahaan maupun real estate, maupun investasi di sektor ekonomi lain termasuk kasino, perhotelan, maupun restoran yang mudah untuk mencairkan kembali dana tersebut.

Sumber dana awal diperoleh melalui kegiatan kriminal. Hal ini terbukti karena ditemukan hubungan- 
hubungan antara jaringan terorisme dan jaringan kriminal. Jaringan terorisme ditemukan mempunyai kedekatan geografis dengan persebaran jaringan penjualan narkotika, sebagai contoh jaringan Al Qaeda di Afganistan dan pemberontak Kun Sa di Myanmar melakukan aksi di wilayah produksi opium terbesar d dunia.

Kegiatan kriminal merupakan
unsur penting dalam pendanaan
terorisme. Sumber penghasil dana terbesar bagi jaringan teroris adalah penjualan narkotika. Tetapi ada beberapa modus lain yang digunakan seperti pemerasan, perampokan, penyanderaan dengan permintaan uang tebusan, penjualan batu mulia, dan penjualan manusia.

Pada tahun 1970, dalam perkembangan teroris di Indonesia, mulai diketahui bahwa kelompok teroris membutuhkan dana dalam setiap aksi teror yang mereka lakukan. Hal ini diketahui dengan adanya kelompok teror Warman yang melakukan serangan teror untuk mencari dana sebanyak banyaknya guna membiayai aksinya. Perkembangan pendanaan terorisme berlanjut hingga tahun 2000an, dilakukan dengan aksifai', yakni perampokan. Pengungkapan aksi pendanaan teroris terbaru ditemukan pada Maret tahun 2015, ketika Detasemen Khusus Antiteror 88 (Densus 88) berhasil menangkap penyandang dana sekaligus perekrut ISIS dari Indonesia. Dalam melakukan pengumpulan dana, para teroris bekerja secara terorganisir, baik dalam kelompok kecil maupun besar. Hal tersebut dilakukan teroris dengan melakukan pembagian tugas kepada masing - masing anggotanya serta mempermudah pengumpulan dana.

Terdapat dua bentuk pengumpulan dana teroris, yakni legal dan ilegal. Kegiatan legal dilakukan dengan bentuk kegiatan seperti sumbangan anggota jaringan teror dan simpatisan baik yang berada di dalam maupun luar negeri.

Pada dasarnya setiap tindak pidana pasti akan menyebabkan rasa tidak aman, baik perorangan maupun dalam masyarakatdan yang pasti juga dapat menimbulkan kerugian negara, keresahan, rasa was-was dan dapat membuat tidak adanya perdamian diantara orang. Tetapi akibat yang ditimbulkan suatu kejahatan pada umumnya tidaklah sedahsyat akibat kejahatan yang disebabkan kejahatan terorisme. 


Berdasar pengertian $\begin{array}{r}\text { tersebut } \\ \text { kegiatan }\end{array}$
maka suatu
terorisme setidaknya meliputi keadaan
berikut :
a. Ditujukan untuk menimbulkan
bahaya terhadap keamanan,
perdamaian dunia serta merugikan
kesejahteraan masyarakat secara
luas

b. Ancaman serius terhadap kedaulatan setiap Negara

c. Mempunyai jaringan nasional dan atau international

d. Diperkirakan mempunyai dana yang tidak kecil yang bersumber dari dalam dan luar

e. Tujuan lain yang hendak dicapai berdimensi ideologis hukum dan konstitusi atau praktis.

Kegiatan ilegal dilakukan dengan perbuatan tindak pidana seperti perampokan bank dan lembaga keuangan milik pemerintah, toko emas, pengusaha non muslim, kejahatan ITE/cyber serta pencucian uang dengan menyelenggarakan usaha yang nampak legal. Para teroris mulai masuk dalam sektor perbankan dengan menggunakan nama samaran untuk menyembunyikan identitas asli dan tujuan penggunaan dana dalam rekening.
Penggalangan dana untuk kegiatan terorisme di Indonesia juga terdeteksi berasal dari beberapa bisnis legal. Sebagai contoh dalam penggalang dana terbesar untuk kelompok Dulmatin adalah Jaja, teroris yang tertembak di Aceh. Jaja yang tertembak di Leupung, Aceh Besar adalah bergerak di bisnis ekspedisi, tambak, dan perbengkelan.Secara hukum, semua bisnis Jaja legal. Dengan dana pribadi Jaja itulah aksi terorisme Dulmatin disupport. Salah satu perusahaan dan bisnis Jaja yang dipakai untuk mendanai teroris adalah CV Sajira Media Karya.Selama ini, perusahaan ini tak pernah dihentikan operasinya oleh kepolisian.Dulmatin yang ahli dalam propaganda berhasil menarik Jaja menjadi donatur. Dan, sejak menyatakan baiat ke Dulmatin, seluruh sumber dana dan jaringan Jaja tunduk pada komando Dulmatin. Dana pelatihan teror jihad ala Dulmatin diindikasikan berasal dari empat jalur.

a) Sisa dana "jihad" Mindanao. Dana ini sebagian berupa mata uang peso yang sudah diuangkan di Kota General Santos, Filipina.

b) Kedua, sumbangan faksi-faksi teroris di luar negeri yang disalurkan melalui jalur Malaysia, 
Thailand Selatan, dan Filipina.

Sebagian uang dolar sudah diuangkan di money changer Menteng senilai USD 1.100 . Diperoleh data dari Densus 88 sendiri berupa cap keluar masuk check point Imigrasi di paspor atas nama Yahya Ibrahim.

c) Dana sunduq (iuran) anggota jaringan. Besarnya bervariasi mulai Rp 100 ribu hingga jutaan rupiah per orang. Beberapa orang mengaku dikenakan kewajiban menyetor dana jihad dalam jumlah besar, tak peduli dari mana asalnya. Ini mengadopsi cara kelompok Negara Islam Indonesia dalam mengembangkan organisasinya.

d) Sumbangan donatur dalam negeri. Polisi mencurigai beberapa nama yang diduga memberikan sumbangan dalam jumlah besar.

Pendanaan tersebut dihimpun dari beberapa wilayah di Indonesia namun kepolisian sulit untuk melakukan penangkapan tanpa bukti yang cukup karena proses pendanaan memang dilakukan melalui bisnis legal dengan uang hasil money laundering., sehingga pemerintah mencoba mengaitkan dengan system perjanjiannya.

\section{Simpulan}

Hawala adalah suatu perjanjian antara 2 orang yang kemudian melibatkan pihak ketiga, yang dapat menjadi ancaman bagi tindakan terorisme yang merupakan momokmenakutkan dan menjadi ancaman di masa yang akan datang. Meskipun para pelaku teror telah tertangkap bahkan ada yang telah diadili dan menjalani hukuman namun hal tersebut tidak menjamin tindakan terorisme akan berhenti begitu saja. Satu hal yang dapat mencegah kegiatan terorisme adalah dengan mengetahui bagaimana uang bekerja dalam tindakan penyebaran terorisme. Walaupun dana yang digunakan dalam tindakan terorisme tidak begitu besar, namun mampu memberikan kerugian yang cukup luar biasa baik traumatik dan jumlah korban jiwa yang tidak sedikit. Untuk mencegah dan mengurangi banyak pihak yang harus terlibat dalam pencegahan tindakan pendanaan terorisme. 


\section{DAFTAR PUSTAKA}

Badr, G. M. (1978). Ialamic Law: Its Relation to Other Legal Systems. The American Journal of Comparative Law, 26(2), 24-25.

Bennett Seftel Hawala Networks. (2017). Bennett Seftel Hawala Networks: The Paperless Trail of Terrorist Transactions.

Force, F. A. T. (2008). Terrorist
Financing. New York.

Redaksi. (2003). PP Dan Undangundang Tentang Pemberantasan Tidak Pidana Terorisme dan Kepolisian Negara Tahun 2002. Jakarta: Tamita Utama.

Thefreedictionary. (n.d.). No Title. Retrieved from Www.thefreedictionary.com/ "HAWALA" 